\title{
China's Guangdong-Hong Kong-Macao Greater Bay Area: A Primer
}

\author{
KERRY LIU
}

\begin{abstract}
On 18 February 2019, China released the 'Development Plan Outline for the Guangdong-Hong Kong-Macao Greater Bay Area (GBA)'. This study presents the most up-to-date analysis on the GBA, including its history, importance and institutional arrangement; its significance vis-à-vis the integration of Hong Kong and Macau to China, to the One Belt One Road initiative, to the Made in China 2025 plan and to China's wider economic growth; and offers a prediction on the GBA's future and the challenges ahead.
\end{abstract}

Keywords: Guangdong-Hong Kong-Macao Greater Bay Area, Made in China 2025, One Belt One Road (BRI), microregionalism, regional integration, city clusters

On 18 February 2019, the 'Development Plan Outline for the Guangdong-Hong Kong-Macao Greater Bay Area (GBA)' (hereafter referred to as 'the Outline') was unveiled. This plan was released by the Central Committee of the Communist Party of China (CPC) and the State Council (China's cabinet). It sets both near-term and long-term development objectives for the region. The plan says that by 2022, the framework for an international first-class bay area and world-class city region should be formed; by 2035, the region should have an economic system and mode of development mainly supported by innovation (Wu 2019).

The GBA consists of 11 municipalities, nine of which are located in Mainland China (Guangzhou, Shenzhen, Dongguan, Foshan, Zhuhai, Jiangmen, Zhongshan, Zhaoqing and Huizhou) and two are Special Administrative Regions (Hong Kong and Macao). It can be considered a city-region, defined as one which comprises any major metropolitan area, or contiguous set of metropolitan areas, together with a surrounding hinterland - itself a locus of scattered urban settlements - whose internal economic and political affairs are intricately bound up with far-flung and intensifying extranational relationships (Scott 2001). A cityregion is characterized by the spatial extent of closely linked economic activity, rather than just the 'city' itself or the jurisdictional definition 
of the settlement. A similar concept is the city/urban cluster (Jha 2019), defined as a geographic concentration of interconnected companies and institutions in a particular field, linked by commonalities and complementarities (Porter 1998).

While there are expanding literatures on supranational regional integration, microregionalism refers to processes of growing regional interconnectedness that occur 'below' the national level which cuts across national borders (Breslin and Hook 2002). The GBA is an example of microregionalism and has been examined by scholars before the concept of a GBA was formally specified. For example, Bie, Jong and Derudder (2015) reviewed the historical evolution of this geographic region, which was generally referred as the Greater Pearl River Delta, in a number of distinct phases and concluded that since 2014 the population, economic clout and mutual interconnectedness, production and R\&D here have grown to such an extent that it can indeed be qualified as a global cityregion. Enright, Scott and Chang (2005) showed how this region benefited from China's economic opening up by combining the international orientation, business experience and financial strength of Hong Kong and Macao with the land, labour and skills from Mainland China, and then became home to one of the world's leading manufacturing centres. Yang (2006) examined the geopolitics of cross-boundary governance, especially the power relations among multiple levels of governments and concerned stakeholders in this region, using the example of the Hong Kong-Zhuhai-Macau Bridge. Cheung (2012) also considered the intergovernmental dynamics within this region using the example of the pursuit of a new reform and development plan by Guangdong province in 2008 and Hong Kong's effort to position itself in China's 12th FiveYear Plan. Yang and Li (2013) examined the restructuring of regional governance since the mid-2000s, reflected in rescaling attempts initiated by the Guangdong provincial government and bottom-up resistance from local residents in Hong Kong, and concluded that the interaction of the rescaling dynamics has engendered a contested geopolitics of cross-boundary governance as regional integration intensifies. Unlike other city-regions in the world, China's GBA is heavily influenced by top-down planning from Chinese central government. The Outline released in February 2019 provides new definitions and policy positionings towards the GBA. From this point of view, this study presents the most up-to-date analysis on the GBA and contributes to the academic literature on microregionalism. 
Regarding studies on clusters, as argued by Wolman and Hincapie (2015) we know a good deal about how clusters operate but much less about how they are formed and, in particular, the extent to which they can be assisted either in their formation or in operation through public policy. So, the natural question is, as put forward by Wolman and Hincapie (2015): since clusters result from natural processes - privatesector, organic, market-driven activity - can public policy improve the functioning of clusters and, if so, through what means? Wolman and Hincapie (2015) concluded that systematic objective evaluation research on cluster-based economic development policy outcomes is badly needed. Furthermore, as argued by Bertaud (2016), China's urban clusters are very different from traditional forms of urbanization, and their size is unprecedented. The GBA will thus be a great example for examination.

Moreover, this study also contributes to the interests of investors who are considering investing in the GBA and the related industries/companies, and other stakeholders as well.

The structure of this article is as follows. Section 1 presents an introduction to the GBA, including its history, importance and institutional arrangement. Section 2 analyses the significance of the GBA to China. Section 3 looks at the future of the GBA. Section 4 concludes the article.

\section{The GBA: Some Background Information}

The concept of a GBA was first mentioned on 28 March 2015 in the 'Vision and Action to Promote the Silk Road Economic Belt and the 21st-Century Maritime Silk Road' jointly issued by China's National Development and Reform Commission, the Ministry of Foreign Affairs and the Ministry of Commerce. In March 2016, the GBA was further mentioned in the '13th Five-Year Plan Outline for National Economic and Social Development', which lays down the strategy and pathway for China's development for 2016-2020. In March 2017, the GBA was discussed by Chinese Premier Li Keqiang during his 'Report on the Work of the Government in 2017'. On 1 July 2017, the 20th anniversary of Hong Kong's handover from Britain to China, the 'Framework Agreement on Promoting the Development of the GBA' was jointly assigned by China's National Development and Reform Commission, Guangdong Provincial Government, Hong Kong Special Administrative Region Government and the government of the Macao Special Administrative Region. In March 2018, Chinese Premier Li Keqiang, during his 'Report on the Work 
of the Government in 2018', stated that the development plan outline would soon be released. In August 2018, Chinese central government established the Leading Committee for the GBA. Then on 28 October 2018, Chinese President Xi Jinping stated that China should do a good job in developing the GBA (CCTV 2018), ${ }^{1}$ indicating that the GBA has gained support from the highest level of Chinese state power.

As stated previously, the GBA consists of 11 municipalities, including Hong Kong and Macau, and nine located in Guangdong Province, Mainland China (Guangzhou, Shenzhen, Dongguan, Foshan, Zhuhai, Jiangmen, Zhongshan, Zhaoqing and Huizhou). The geographic location is shown in Figure 1.

FIGURE 1. China's GBA: Geographic Location

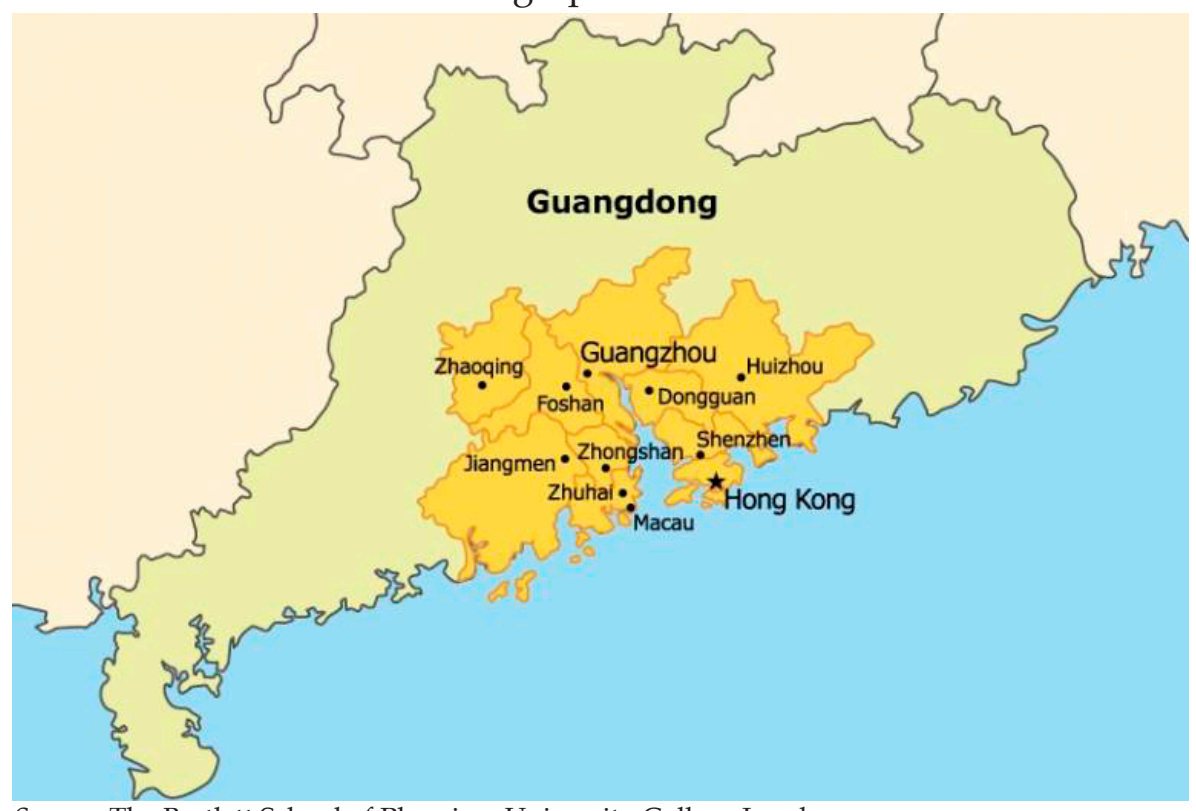

Source: The Bartlett School of Planning, University College London

Each municipality has unique characteristics. For example, while the manufacturing sector in Hong Kong is negligible, Hong Kong is an international centre for finance such as offshore Renminbi and asset management, logistics and trade. Hong Kong also has world-class universities. Macau's main sector is gaming and tourism, and the convention and exhibition business. Guangzhou is the capital and transport hub of Guangdong Province, with both heavy industry such as auto manufacturing and light industry and the service industry. Shenzhen is famous for its high-tech industries such as Huawei, ZTE and BYD, while lacking in terms of higher education opportunities. Dongguan and Foshan 
are major manufacturing hubs. Zhuhai mainly relies on light industry. The rest are relatively underdeveloped. Table 1 shows the land areas, populations and GDP of the various parts of the GBA.

TABLE 1. The Land Area, Population and GDP of the GBA (2017; Ranked by GDP)

\begin{tabular}{|l|r|r|r|}
\hline & $\begin{array}{r}\text { Land area } \\
\left(\mathrm{km}^{2}\right)\end{array}$ & $\begin{array}{r}\text { Population } \\
\text { million })\end{array}$ & $\begin{array}{r}\text { GDP } \\
(\text { US\$ bn) }\end{array}$ \\
\hline Guangzhou & $7,434.4$ & 14.5 & 351.0 \\
\hline Shenzhen & $1,997.5$ & 12.5 & 345.4 \\
\hline Hong Kong & $1,073.0$ & 7.4 & 341.5 \\
\hline Foshan & $3,797.7$ & 7.7 & 144.3 \\
\hline Dongguan & $2,460.0$ & 8.3 & 116.4 \\
\hline Huizhou & $11,347.0$ & 4.8 & 58.8 \\
\hline Zhongshan & $1,783.7$ & 3.3 & 52.7 \\
\hline Macau & 30.4 & 0.6 & 50.4 \\
\hline Jiangmen & $9,505.0$ & 4.6 & 41.3 \\
\hline Zhuhai & $1,736.5$ & 1.8 & 41.1 \\
\hline Zhaoqing & $14,891.0$ & 4.1 & 32.4 \\
\hline Total & $56,056.1$ & 69.5 & $1,575.3$ \\
\hline World Rank & 123 & 20 & 12 \\
\hline Comparison to & & & \\
China (Excluding & $0.6 \%$ & $4.4 \%$ & $9.4 \%$ \\
Hong Kong and & & & \\
Macau) & & & \\
\hline
\end{tabular}

Source and note: The land area data are from the government's official website, and no water areas are included; population and GDP data are from Wind and China's National Bureau of Statistics. The world rank data are from the United Nations Statistics Division. GDP rank data are from the World Bank and United Nations. All data are as of 2017 or the most recent available.

Table 1 shows that the total area of the GBA is around 56,056 square kilometres, the total population is 69.5 million and the total GDP is approximately US $\$ 1.58$ trillion as of 2017. If considering the GBA as a country, it is ranked 123 rd by area, 20 th by population and 12 th by GDP in the world. Its population is greater than those of the UK and France, just behind Turkey. Its GDP is bigger than that of Russia, Australia or Spain, just behind South Korea. Comparing the GBA to China (excluding Hong Kong and Macau), it only accounts for 0.6 per cent by area, 4.4 per cent by population but 9.4 per cent by GDP. The fractions will fall slightly if including Hong Kong and Macau as parts of China. In comparison to other city-regions, the GBA is the third largest by GDP, behind the New York Metropolitan area (US\$1.66 trillion) and the Tokyo bay area (US\$1.77 trillion) but is the largest in terms of population. ${ }^{2}$ 
There are some institutional arrangements regarding promoting the development of the GBA. For example, a Leading Committee on Building the GBA was established in 2018. The team members are shown in Table 2.

TABLE 2. The Members of the Leading Committee on Building the GBA

\begin{tabular}{|c|c|c|}
\hline & Name & Positions \\
\hline $\begin{array}{l}\text { Team } \\
\text { Leader }\end{array}$ & Han Zheng & $\begin{array}{l}\text { Standing Committee Member of the } \\
\text { Political Bureau of the CPC Central } \\
\text { Committee; Vice-Premier of China }\end{array}$ \\
\hline \multirow[t]{2}{*}{$\begin{array}{l}\text { Deputy } \\
\text { Team } \\
\text { Leader }\end{array}$} & $\mathrm{Li} \mathrm{Xi}$ & $\begin{array}{l}\text { Member of the Political Bureau } \\
\text { of the CPC Central Committee; } \\
\text { Guangdong Provincial Party Com- } \\
\text { mittee Secretary }\end{array}$ \\
\hline & He Lifeng & $\begin{array}{l}\text { Director of the National Develop- } \\
\text { ment and Reform Commission }\end{array}$ \\
\hline \multirow{5}{*}{$\begin{array}{l}\text { Team } \\
\text { Member }\end{array}$} & $\begin{array}{l}\text { Carrie Lam Cheng } \\
\text { Yuet-ngor }\end{array}$ & Chief Executive of Hong Kong \\
\hline & $\begin{array}{l}\text { Fernando Chui Sai } \\
\text { On }\end{array}$ & Chief Executive of Macau \\
\hline & Zhang Xiaoming & $\begin{array}{l}\text { Director of the Hong Kong and } \\
\text { Macau Affairs Office, China }\end{array}$ \\
\hline & Wang Zhimin & $\begin{array}{l}\text { Director of the Liaison Office of the } \\
\text { Chinese Central Government in } \\
\text { Hong Kong }\end{array}$ \\
\hline & Fu Ziying & $\begin{array}{l}\text { Director of the Liaison Office of } \\
\text { the Chinese Central Government } \\
\text { in Macau }\end{array}$ \\
\hline
\end{tabular}

Source: 21CNH 3 , 2018; Xinhua News, 2019; Jiang, 2019

According to the 2017 'Framework Agreement on Promoting the Development of the GBA', the quartet - that is, the National Development and Reform Commission, Guangdong Province, Hong Kong and Macau governments - will hold regular meetings every year to coordinate and resolve major issues in the development of the GBA. After the Leading Committee on Building the GBA was established, this committee is assumed to undertake the responsibilities of coordination and implementation. 


\section{The GBA's Significance}

Since the GBA was initialized by and is now under the planning of Chinese central government, it bears the responsibility of fulfilling the objectives of the latter. Specifically, there are four policy objectives: further integrating Hong Kong and Macau into Mainland China; extending the One Belt One Road Initiative (BRI); further implementing economic structure upgrading and promoting the Made in China 2025 programme; enhancing economic growth. In a word, the GBA initiative plays a significant role in China's national strategy.

\section{A. Further Integrating Hong Kong and Macau into Mainland China}

Hong Kong was ruled by Great Britain from 1842 to 1997. After 1 July 1997, it was transferred to China under the arrangement of 'One Country, Two Systems'. Chapter 1, Article 5 of the Hong Kong Basic Law, the constitutional document of the Hong Kong Special Administrative Region, reads: 'the socialist system and policies shall not be practised in the Hong Kong Special Administrative Region, and the previous capitalist system and way of life shall remain unchanged for 50 years'.

However, since Hong Kong's return to China, a majority of the population is pessimistic about the future (Cheng 2014). At the same time, localism - referring to a political movement that focuses on the preservation of Hong Kong's identity and autonomy - is rising. People of this view generally object to growing political encroachment by the Beijing government into Hong Kong's political, economic and social affairs. Trust of the Beijing government has dropped significantly. For example, in late 2008, the year of the Beijing Olympics, 53.1 per cent of respondents trusted the Beijing government, with only 14.4 per cent not trusting it. By the end of 2015, about 40 per cent did not trust the Beijing government, with only 35.2 per cent trusting it (Kwong 2016).

In reality, Hong Kong is moving toward 'One Country, One and a Half Systems', and the Chinese government's approach is approaching 'One Country, OneSystem' (UK Parliament 2019). One major method is through the cross-border integration. For example, as argued by Yang (2006), establishment of the Closer Economic Partnership Arrangement (CEPA) in 2003 has indicated that cross-border integration between Hong Kong and China has shifted authority to the central government. As the GBA means a deeper integration between Hong Kong, Macau and Mainland China, the result would be much closer to 'One Country, One System'. 
Localism in Macau is much weaker than in Hong Kong but the approaches and effects are very similar.

\section{B. Further Promoting the BRI}

In 2013, Chinese President Xi Jinping launched the BRI, calling it the 'project of the century' (Clover et al. 2017). The BRI broadly emphasizes cooperation in five areas: coordinating development policies; forging infrastructure and facilities networks; strengthening investment and trade relations; enhancing financial cooperation; and deepening social and cultural exchanges (Johnston 2019). It is also argued that the BRI has emerged as the cornerstone of China's economic statecraft. Under the umbrella of the BRI, China seeks to promote a more connected world brought together by a web of Chinese-funded physical and digital infrastructure, which is a key tool for advancing China's geopolitical ambitions. Through the economic activities bundled under the BRI, China is pursuing a vision of the twenty-first century defined by great power spheres of influence, state-directed economic interactions and creeping authoritarianism (Kliman et al. 2019). ${ }^{5}$

The BRI includes the Silk Road Economic Belt and the twenty-firstcentury Maritime Silk Road; the starting point for the latter is the GBA (see Figure 2).

FIGURE 2. China's BRI and the GBA

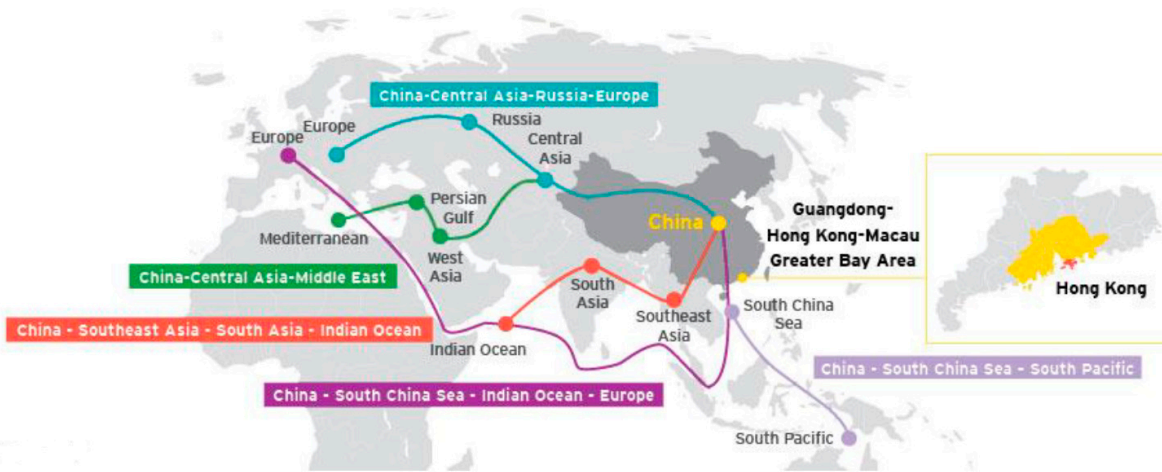

Source: CCTV, Education University of Hong Kong

The role of the GBA is twofold. First, the Mainland China part of the GBA, that in Guangdong Province, is an important source of China's outward direct investment (ODI). For example, as of 2017, Guangdong accounts for 10.5 per cent of Chinese ODI stocks, while this figure was just 5.2 per cent in $2013 .{ }^{6}$ Guangdong Province has increasingly become an important source of Chinese ODI, including in BRI projects. Second, 
Hong Kong plays a very important role in providing financing and investment, and professional services to BRI projects. Specifically, in the first place, Hong Kong as a major financing centre can offer financings for BRI projects. In 2018, Hong Kong took the top slot in global Initial Public Offering rankings, and more than 70 per cent of the funds raised came from mainland enterprises (Luo 2018). Hong Kong was ranked number one globally for five years for the size of initial public offerings, and in the top five for four years during 2009-2017 (FSDC 2018). ${ }^{7}$ In terms of bank loans, 70 of the world's 100 largest banks operate in Hong Kong, and the total banking assets are around US\$3 trillion as of 2017 (FSDC 2018). In addition, the efficient and sophisticated finance infrastructure in Hong Kong also makes it possible to supply different types of sovereign bonds, municipal bonds, corporate bonds and other types of bonds from BRI. Moreover, Hong Kong is developing its green bond market to finance infrastructure projects with some ecological requirements. For example, the Hong Kong Quality Assurance Agency has launched a green finance certification scheme to provide third-party conformity assessments for issuers on their green financial instruments by making reference to international and national standards. Hong Kong is also the leading offshore Renminbi (RMB) centre. As of December 2017, around 50 per cent of global offshore RMB deposits are at banks in Hong Kong (FSDC 2018). In order to promote Hong Kong's financial support of the BRI, the Hong Kong Monetary Authority Infrastructure Financing Facilitating Office was established in July 2016. As argued by Chan (2018), given the huge infrastructure demand, the BRI would require multiple sources and mechanisms of funding; a market-oriented, multitier system of financing is the only feasible way to provide sustainable funding for cross-border infrastructure projects. Hong Kong seems to be the sole candidate in China that can fulfil this role. Next, Hong Kong can provide professional insurance and reinsurance services to BRI projects. For example, Hong Kong can provide feasibility evaluation, risk assessment, planning, design, construction, supervision, management and maintenance services in this area. Hong Kong is also able to offer services such as environmental impact assessment, green building and pollution control.

While Hong Kong alone can do these jobs for BRI projects, Hong Kong as a part of GBA can do an even better job. A more integrated financial and non-financial market within the GBA will further enhance Hong Kong's leading role of financial and professional services. For instance, for stock markets, a single market in which all major firms in 
BRI countries are trading is assumed to be centred around Hong Kong (and Shenzhen). The Hong Kong Exchanges and Clearing will also benefit from its expanding business of conducting commodities trading in the Qianhai SEZ located in a suburb of Shenzhen (Lau 2018). As Hong Kong already has the highest concentration of insurers in Asia (FSDC 2018), and is expected to continue as a buyers' market (WTW 2018), ${ }^{8}$ a more integrated GBA will provide more opportunities for and further strengthen the insurance industry in Hong Kong.

More importantly, the establishment of the GBA is consistent with the broad strategic goals set by the BRI. As discussed above, the BRI emphasizes the importance of forging infrastructure and facilities networks, through which China seeks to promote a more connected world brought together by a web of physical and digital infrastructure for advancing its geopolitical ambitions. A more integrated GBA in terms of infrastructure, investment and trade will naturally be connected with the BRI areas, thus creating a more broadly integrated world including both domestic and overseas markets.

\section{Further Upgrading Economic Structure and Promoting the Made in China 2025 Programme}

Table 3 shows the GDP structure by industry in the GBA. It shows that while the manufacturing industry in Hong Kong and Macau is almost negligible, manufacturing is the dominant industry in the rest of the GBA, in other words the nine relevant cities of Mainland China. This finding is consistent with that from the national-level data. For example, Liu (2018) found that China accounted for almost one quarter (23.6 per cent) of world manufacturing output in 2016, followed by the USA (15.6 per cent), Japan (10 per cent) and Germany (6.3 per cent). China surpassed the USA as the leading manufacturing economy in 2010. China is clearly the world's largest manufacturing economy.

However, despite the clear dominant position of the manufacturing industry, it seems that this industry structure needs to be further upgraded. For example, RG (2019) found that manufacturing in the GBA is relatively lacking in high-level talent, the degree of digital integration is not high and the whole development model seems to be labour intensive. ${ }^{9}$ This finding is consistent with those based on national-level data. For example, Liu (2018) found that China's production and exports are still more focused on lower-tech manufacturing sectors than those of other countries.

As argued by Kenderdine (2017), China's transition economy experiment continues to rely heavily on state-driven industrial policy to 
Kerry Liu

TABLE 3. The GDP Structure by Industry in the GBA (2017)

\begin{tabular}{|l|c|c|c|c|c|c|}
\hline & $\begin{array}{c}\text { Agri- } \\
\text { culture }\end{array}$ & $\begin{array}{c}\text { Manufac- } \\
\text { turing }\end{array}$ & $\begin{array}{c}\text { Industrial } \\
\text { Industry }\end{array}$ & $\begin{array}{c}\text { Wholesale } \\
\text { and Retail } \\
\text { Sales }\end{array}$ & $\begin{array}{c}\text { Finance } \\
\text { and In- } \\
\text { surance }\end{array}$ & $\begin{array}{c}\text { Real } \\
\text { Estate }\end{array}$ \\
\hline Guangzhou & $1.1 \%$ & $/$ & $25.4 \%$ & $14.7 \%$ & $9.1 \%$ & $8.5 \%$ \\
\hline Shenzhen & $0.1 \%$ & $/$ & $38.6 \%$ & $10.5 \%$ & $13.0 \%$ & $/$ \\
\hline Zhuhai & $1.8 \%$ & $/$ & $42.4 \%$ & $/$ & $/$ & $/$ \\
\hline Foshan & $1.4 \%$ & $/$ & $55.7 \%$ & $6.8 \%$ & $4.3 \%$ & $8.9 \%$ \\
\hline Jiangmen & $7.0 \%$ & $/$ & $46.6 \%$ & $7.4 \%$ & $5.0 \%$ & $6.1 \%$ \\
\hline Zhaoqing & $15.5 \%$ & $/$ & $33.5 \%$ & $9.8 \%$ & $3.5 \%$ & $6.1 \%$ \\
\hline Huizhou & $4.3 \%$ & $/$ & $49.6 \%$ & $10.3 \%$ & $4.9 \%$ & $8.4 \%$ \\
\hline Dongguan & $0.3 \%$ & $/$ & $47.1 \%$ & $11.5 \%$ & $6.0 \%$ & $8.7 \%$ \\
\hline Zhongshan & $1.6 \%$ & $/$ & $48.1 \%$ & $9.8 \%$ & $5.8 \%$ & $7.7 \%$ \\
\hline Hong Kong & $0.1 \%$ & $1.0 \%$ & $<2.4 \%$ & $21.2 \%$ & $17.5 \%$ & $10.5 \%$ \\
\hline Macau & $/$ & $0.6 \%$ & $1.3 \%$ & $5.6 \%$ & $6.5 \%$ & $10.6 \%$ \\
\hline
\end{tabular}

Source: Wind Info. Accessed from https://www.wind.com.cn/en/

Note: / represents data not available. The nine mainland cities did not separately record their manufacturing industry. Accordingly, the industrial industry is regarded as a proxy indicator approximately measuring the manufacturing industry. In Hong Kong, the agricultural industry is recorded together with mining industry, accounting for about 0.1 per cent of GDP. The electricity, gas and water supply accounts for less than 1.3 per cent of GDP, so overall industrial industry accounts for less than 2.4 per cent. Hong Kong's wholesale and retails also includes foreign trade, and the real estate industry also includes professional services such as lawyers, accountants, financial advisers and consultants, among others. In Macau, electricity, gas and water supply accounts for 0.7 per cent of GDP, and there is no reporting on the mining industry. Therefore, the overall industrial industry accounts for around 1.3 per cent.

structure the economy. Accordingly, China launched Made in China 2025, a ten-year strategic plan to comprehensively upgrade China's manufacturing industry. The strategic goal of Made in China 2025 is to make China a manufacturing powerhouse in terms of quality as well as quantity. It has five principles: to be innovation driven; to be high quality; to showcase eco-development; to achieve structural optimization; to be talent oriented (Liu 2018).

As a response to the Made in China 2025 programme launched by Chinese central government, the local governments in the GBA also made their own industrial policies to connect with, or 'dock', the national Made in China 2025. For example, in January 2016 the Shenzhen government launched the 'Shenzhen Action Plan for Docking Made in China 2025'. In March 2018, Guangdong Provincial government issued the 'Implementation Plan and Supporting Policy Measures on Deepening The "Internet + Advanced Manufacturing" and Developing Industrial Internet'. In November 2018, the Shenzhen government issued the 'Implementation Plan on Further Accelerating the Development of Strategic Emerging Industries'. In July 2018, it was reported that Guangdong 
Provincial government was working with the Hong Kong and Macau governments to draft a 'Science and Technology Innovation Action Plan for the GBA for 2018-22' (China News 2018). ${ }^{10}$

While Liu (2018) summarized the strategies the Chinese government has adopted to implement the industry policies, the specific measure for the GBA is collaboration in areas relevant to the structural upgrading of Chinese manufacturing between Mainland China and Hong Kong, whose universities are strong in scientific research. For example, R\&D collaboration of the following areas is to be further strengthened (HKAES 2017):

- Advanced manufacturing including robotics; industrial integrated systems; new energy vehicles; intelligent automobiles; advanced energy storage batteries; high-end marine equipment; avionics; wearable devices.

- Big Data science and e-commerce including Big Financial Data; cloud computing, social networking, data mining; smart city; pattern recognition; information security technology; sensor technology.

- Biotechnology including pharmaceuticals; targeted drugs; chiral drugs and the like.

- Environment and urban governance, including water pollution control; smart cities; marine pollution control; environmental monitoring technology; haze governance technology.

- Energy saving and new energy, including renewables such as solar, wind, wave, biological power, high-efficiency thin-film photovoltaic cells and the like.

- Medical health including aging; disease treatment such as cancer, hepatitis B, diabetes mellitus, and so on.

- New materials including nanometer material; new biomimetic materials.

Furthermore, a more integrated GBA will also help improve the competitiveness of the manufacturing industry. For example, more infrastructure investments (roads, ports, airports and so on) and greater logistics capabilities will make it easier to find alternative suppliers and further improve the movement of goods. These are essential parts of the supply chain. The much easier access to financing (equity, debt or trade-related financing) will further help cross-border trade flows in and out of the GBA (Qu and Lam 2018).

\section{Further Promoting Economic Growth}

China's economic growth has been continuously declining since its high in 2007 before the global financial crisis, when the Chinese economy 
grew 14.2 per cent. The figure was just 6.6 per cent in 2018. As argued by Liu (2018), the change in China's growth trend reflects both cyclical and structural problems but mainly the latter. The main reason for China's economic slowdown is the decline of its potential GDP growth rate, which is determined by three factors: labour, capital and total factor productivity. First, China's ongoing transition from a relatively young workforce to a more elderly population is affecting China's demographic dividend. Second, much evidence shows China has been overinvesting in many sectors. Third, over the past 40 years of rapid economic growth in China, the impressive performance in total factor productivity has largely been attributed to resource allocative efficiency through labour mobility from agricultural to non-agricultural sectors. As the surplus labour force has become gradually absorbed by the expansion of secondary and tertiary sectors, mass labour migration has slowed, and the opportunity to enhance resource allocative efficiency has decreased. Various measures can be adopted to enhance the potential GDP growth rate, such as supplying more labour and improving productivity. While abolishing the one-child policy, so as to increase labour supply, and further opening up China's domestic market are positive initiatives, overall progress is very small. Institutional reforms, which are assumed to improve total factor productivity, are proceeding very slowly (Liu 2018).

Under such conditions, to further promote regional integration has become an important task. Although the key concept of this study is the microregionalism, studies based on macroregionalism can still be applied. The main reason is that the essence of the regionalism is very similar in both cases. For example, although the degree of integration varies, they generally include the abolishment of tariffs, and the abolishment of restrictions on factor and commodity movements (Balassa 2013). Studies have found that economic integration can enhance growth. For example, for developed economies, closer integration can be achieved by increasing trade in goods or by increasing flows of ideas. Either form of integration can increase the long-run rate of growth (Rivera-Batiz and Romer 1991). Using a data set of around 100 developing countries over 1970-2004, Te Velde (2011) found that regional integration has a positive impact on growth in its members through the effects of increased trade and investment.

Regarding the GBA, with the completion of the Hong KongZhuhai-Macau Bridge and several other infrastructure projects, there will be significantly increased connectivity amongst these 11 cities, pro- 
viding an engine of accelerated growth for the entire GBA. Increased connectivity can foster trade in goods and services and direct investments that did not exist before, thus adding new value (Lau 2018). Furthermore, the abolishment of legal and other barriers will also add new value.

\section{Future of the GBA}

It is expected that the infrastructure facilities in the GBA will be more interconnected, and the GBA will be more integrated in the future in terms of goods, services, investment and people. As a result of this deeper integration, scientific and innovation activity will be further improved in the GBA.

\section{A. Infrastructure Interconnection and Sharing}

The Outline states that there will be more infrastructure facilities within the GBA for improving interconnection and sharing. Table 4 shows recent and future developments of regional connectivity infrastructures.

TABLE 4. Development of Regional Connectivity Infrastructures for the GBA

\begin{tabular}{|l|l|l|}
\hline Name & Function & Timeline \\
\hline $\begin{array}{l}\text { Hong Kong-Zhuhai- } \\
\text { Macau Bridge }\end{array}$ & $\begin{array}{l}\text { Shortening the travel time of the approxi- } \\
\text { mately 42km from Hong Kong Port to Zhuhai } \\
\text { Port and Macao Port to within 40 minutes }\end{array}$ & $\begin{array}{l}\text { Finished in } \\
\text { February } \\
2018\end{array}$ \\
\hline $\begin{array}{l}\text { Guangzhou-Shen- } \\
\text { zhen-Hong Kong } \\
\text { Express Rail Link }\end{array}$ & $\begin{array}{l}\text { High-speed railway line that connects Beijing } \\
\text { and Hong Kong (Kowloon) via Guangzhou } \\
\text { and Shenzhen }\end{array}$ & $\begin{array}{l}\text { Finished in } \\
\text { September } \\
2018\end{array}$ \\
\hline Humen Second Bridge & $\begin{array}{l}\text { Enhancing connection of Guangzhou and } \\
\text { Dongguan }\end{array}$ & $\begin{array}{l}\text { To roll out in } \\
\text { 2019 }\end{array}$ \\
\hline $\begin{array}{l}\text { Guangzhou-Shantou } \\
\text { Express Rail Link }\end{array}$ & $\begin{array}{l}\text { Shortening the trip from Guangzhou to Shan- } \\
\text { tou to 90 minutes }\end{array}$ & $\begin{array}{l}\text { To roll out in } \\
\text { 2020 }\end{array}$ \\
\hline $\begin{array}{l}\text { Shenzhen-Zhongshan } \\
\text { Corridor }\end{array}$ & $\begin{array}{l}\text { Cutting the trip from Shenzhen to Zhongshan } \\
\text { to 30 minutes }\end{array}$ & $\begin{array}{l}\text { To roll out in } \\
\text { Dec 2024 }\end{array}$ \\
\hline
\end{tabular}

Source: Wong (2018); https://www.hzmb.gov.hk/

In particular, the 55km Hong Kong-Zhuhai-Macau Bridge, consisting of the $12 \mathrm{~km}$ Hong Kong Link Road, the $29.6 \mathrm{~km}$ Main Bridge and the $13.4 \mathrm{~km}$ Zhuhai Link Road, is a bridge and tunnel system consisting of a series of three cable-stayed bridges, an undersea tunnel and four artificial islands. ${ }^{11}$ It is the longest bridge-cum-tunnel sea crossing in the world. The total cost was RMB126.9 billion (equivalent to US\$18.3 billion) (Xinhua News, 2018). ${ }^{12}$ Figure 3 shows this bridge. 
FIGURE 3. The Hong Kong-Zhuhai-Macau Bridge

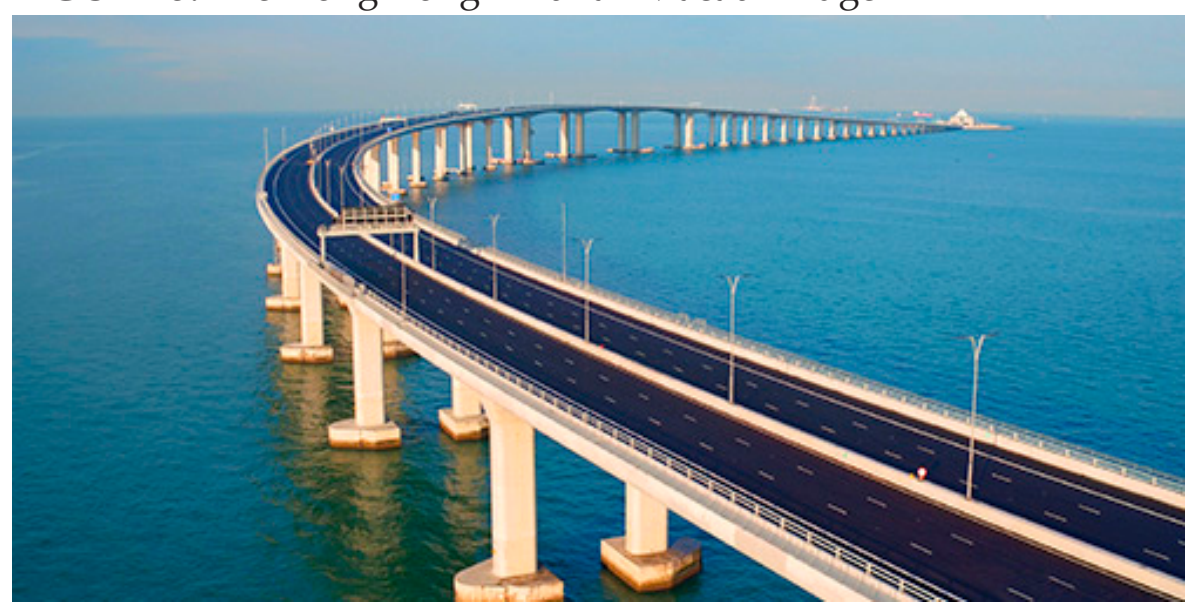

Source: Discover Hong Kong

Furthermore, it is suggested that the GBA should strengthen the coordination and sharing of infrastructures. For example, The GBA can maximize the usage of its airports, tunnels, bridges and seaports by following the example of New York and New Jersey (Lau 2018). The Port Authority of New York and New Jersey, formed in 1921, on behalf of the states of New York and New Jersey, operates and maintains much of the regional transport infrastructure, including airports such as La Guardia Airport, John F. Kennedy International Airport, Newark Liberty International Airport, Teterboro Airport, Stewart International Airport and Atlantic City International Airport, as well as other surface and seaborne transportation facilities. The GBA can establish a GBA Port Authority to manage all the infrastructure facilities in the area, or as suggested by Lau (2018), as the first step just a GBA Airport Authority to manage all the civil airports (or just Hong Kong and Shenzhen airports) in the area.

Besides transportation infrastructure, it is expected that the GBA will also deepen its interconnection and sharing in information infrastructure, such as by upgrading the internet broadband and creating a more standardized smart city for data sharing. A more interconnected energy supply system is also underway, such as through sharing the power grid and gas supply network. A more coordinated water usage system is also expected.

\section{B. A More Integrated GBA Market}

Before the formal GBA, there have already been some mechanisms to help integrate the economies of this region. For example, the CEPA came 
into effect in January 2004 (Yang 2016). The CEPA consists of three parts: trade in goods, trade in services and trade and investment facilitation. In terms of trade in goods, about 90 per cent of Hong Kong's domestic exports to the mainland have enjoyed zero tariffs since January 2004. In terms of trade in services, the package is 'WTO-plus' because the concessions go beyond China's World Trade Organization commitments. Hong Kong businesses will have priority in accessing the mainland market with lower thresholds, especially in a total of 18 service sectors including banks, insurance, legal services, retail and professional services. The CEPA agreement represents a pioneering intervention by Chinese central government to coordinate cross-border economic integration more directly, while previously this process was mainly driven by informal mechanisms such as the market forces, the private sector and lower-level regional governments (Yang 2016). Besides the CEPA, there are also other mechanisms such as the Shenzhen-Hong Kong Innovation Circle Agreement, signed in 2007, and the Hong Kong-Guangdong Co-operation Framework Agreement, signed in 2010.

According to the Outline, the free flow of goods, services, investment and people will be further promoted. In order to enhance free trade, it is suggested to have a trusted authority within the GBA to certify the quality and safety of the goods (Lau 2018). In addition to the free flow of goods, the free flow of services will be further facilitated. For example, Lau (2018) has suggested that courier delivery services should be opened across the whole GBA. Regarding investment, Hong Kong and Macau investors will be further granted special status in terms of market entry in the areas of financial services, education, law and dispute resolution, shipping, logistics, railway transportation, telecommunications, Chinese medicine, construction and related engineering in the GBA. The requirements in terms of qualifications and shareholdings will be further reduced or even cancelled. Regarding the free flow of people, there will be further improvement in simplification and automation of the entry/exit and customs processes within the GBA. The issues of professional qualifications, individual income tax and vehicle traffic management will be further addressed too. However, there is a challenge in that the restrictions will be further lifted for Hong Kong and Macau residents to enjoy benefits in Mainland China but not the other way around. For example, it is possible for middle school and preschool teachers from Hong Kong and Macau to work in the mainland part of the GBA. There is also a possibility that Hong Kong and Macau residents can apply for public service jobs in Mainland China. But to come from 
the other way is not possible at this stage and may still be impossible in the near future.

Furthermore, there will be more collaborations in R\&D between Hong Kong, Macau and Mainland China. The Outline states that Hong Kong and Macau will be further integrated into China's national innovation system. Specifically, the Guangzhou-Shenzhen-Hong Kong-Macau Science and Technology Innovation Corridor will be further promoted, and a big data centre for the GBA will be jointly established. Institutions from Hong Kong and Macau will be encouraged to apply for Mainland China's grants and funds. Lau (2018) predicted that Hong Kong and Shenzhen together could form a global innovation, venture investment, start-up and financing hub in the GBA.

\section{Concluding Remarks}

On 18 February 2019, the central committee of Chinese ruling party and the Chinese government released the development plan Outline for the GBA. This study presents the most up-to-date analysis of the GBA, and contributes to the academic literature on microregionalism, city clusters and relevant stakeholders.

The GBA consists of 11 cities, including Hong Kong, Macau and nine Mainland Chinese cities. Comparing the GBA to China (excluding Hong Kong and Macau), the GBA only accounts for 0.6 per cent by area and 4.4 per cent by population but 9.4 per cent by GDP. Considering the GBA as a country, it would be ranked 123 rd by area, 20 th by population and 12th by GDP in the world. Furthermore, this study analyses four aspects of its significance: further integrating Hong Kong and Macau into Mainland China, promoting the BRI, promoting economic structure upgrading and the Made in China 2025 programme, and enhancing economic growth. It is expected that in the future there will be more infrastructure interconnection and sharing within the GBA and that the GBA market will become more integrated.

However, challenges remain for the future of the GBA. Generally speaking, costs could arise in the process of integration including, for example, the fact that gains could be unevenly distributed. As argued by Venables (2003), integration within a union composed of low-income members tends to lead to divergence of member (country) incomes. Moreover, there could be more conflicts resulting from more interactions between people. Integration may also lead to pushbacks from locals who are losers in the process. 
Specifically, the main challenge is the integration of Hong Kong into Mainland China. For example, Mainland Chinese tourists have increased from 2.36 million, accounting for 21.0 per cent of total tourists visiting Hong Kong in 1997, to 51 million, accounting for 78.3 per cent in 2018. ${ }^{13}$ However, mainland Chinese visitors' wealth, shopping activities, mobility and even physical presence are now felt to be more parasitical, revolting and threatening in Hong Kong (Ip 2015). The resistance and hostility against the Chinese government and mainlanders has led to a new Hong Kong identity and new narratives about Hong Kong's political role in China. Deteriorating human rights records and tightened political control from Beijing since 2008 have aggravated the anti-China sentiments in Hong Kong. The Hong Kong people are becoming more sceptical of increased integration, and the political gap between China and Hong Kong is widening around the struggle for democracy (Ma 2015). The Hong Kong anti-extradition bill protests in 2019 show that Mainland-Hong Kong relations have entered an unprecedentedly difficult period.

There are also economic obstacles. For instance, there are three currencies within the GBA, namely, RMB (used in Mainland China), HK dollars and Macanese pataka (used in Macau). Under the current policy, funds from Mainland China can only be directly transferred offshore under the capital account with approval. China's capital account liberalization ground to a halt after its reform of mechanisms for setting the RMB central parity rate against the US dollar in 2015 (Liu 2016) and the following series of episodes of financial turmoil until 2017. Since then, the Chinese authorities seem to have been very cautious towards policies that could lead to capital outflow. There should be more policy initiatives concerning capital flow within the GBA including Hong Kong and Macau. Furthermore, as argued by Lau (2018), uniform and timely access to the correct information in a market is crucial for the efficiency of the market system. This means ready access to the internet is essential. However, access to the internet is restricted within Mainland China. How to resolve this issue needs to be addressed by Chinese officials.

In essence, the integration of Hong Kong into China is all to do with Beijing's political encroachment in Hong Kong's affairs, and a more liberal market economy with rule of law, private property rights and respect of contracts in a largely state-led economy. There are huge challenges ahead for the Chinese authorities. 
KERRY LIU is an Associate at the China Studies Centre, University of Sydney, Australia. He has been a China economist, working in the private sector across Asia Pacific including Beijing, Hong Kong and Sydney covering China's macroeconomy and financial markets as well as politics. He holds a PhD in Finance from the University of Melbourne (Australia), an MPhil in Economics and a B.Eng. in Mechanics from Tongji University (Shanghai). Since 2016, he has published or has forthcoming papers in journals including Managerial Finance, Research in Economics, Journal of Economic Issues and The Chinese Economy among others. E-mail: Kerry.luke@gmail.com

\section{ACKNOWLEDGEMENT}

The author would like to thank two anonymous referees for very helpful comments on an earlier version of this article. All errors are the author's sole responsibility.

\section{NOTES}

1 CCTV 2018. 'Ba yuegangao dawanqu jianshe zhuajin zhuashi banhao (We will do a good job in developing the GBA)'. http://china.huanqiu.com/article/201810/13380877.html?agt=15422 (in Chinese).

2 Source: Hong Kong Trade Development Council.

3 21CNH 2018. 'Yuegangao dawanqu jianshe lingdao xiaozu jiangkai shouci huiyi hanzheng ren zuzhang (The GBA Leading Committee will have its first meeting)'. 21st-Century Business Herald. http://money.163.com/18/0814/13/ DP63177G002580S6.html (in Chinese).

4 Xinhua News 2019. 'Hanzheng zhuchi zhaokai yuegangao dawanqu jianshe lingdao xiaozu huiyi (Han Zheng presided over the GBA Leading Committee Meeting)'. http://www.gov.cn/guowuyuan/2019-03/01/content_5369786.htm (in Chinese).

5 Kliman, Daniel, Rush Doshi, Kristine Lee and Zack Cooper. 'Grading China's Belt and Road. Center for a New American Security.' April 2019. https:/ / s3.amazonaws. com/files.cnas.org/CNAS+Report_China+Belt+and+Road_final.pdf

6 Source: Wind Info. Accessed from https://www.wind.com.cn/en/

7 FSDC (Financial Service Development Council), 2018. 'Overview of Hong Kong Financial Services Industry'. http://www.fsdc.org.hk/sites/default/files/Overv iew $\% 20$ of $\% 20 \mathrm{HK} \%$ 20Financial\%20Services\%20Industry_E.pdf

8 WTW (Willis Towers Watson) 2018. 'Asia Insurance Market Report 2018'. https:/ / www.willistowerswatson.com/-/media/WTW/PDF/Insights/2018/02/asia-insurance-market-report-2018.pdf

9 RG (Research Group) 2019. 'Digital Economy and Talent Development in the Guangdong- Hong Kong- Macau Greater Bay Area'. https://economicgraph.linkedin. com/content/dam/me/economicgraph/zh-cn/pdfs/digital-economy-talent-development-report-china-greater-bay-area-updated.pdf

10 China News 2018. 'Yuegangao dawanqu kechuang xingdong wunian jihua youwang jinqi shishi (Guangdong, Hong Kong, Macao and Greater Bay Area Science and 
Technology Action Five-Year Plan is expected to be implemented in the near future)'. http://www.chinanews.com/gn/2018/07-27/8582013.shtml (in Chinese).

11 Source: https://www.hzmb.gov.hk/

12 Xinhua News, 23 October 2018. 'World's longest cross-sea bridge opens, integrating China's Greater Bay Area'. http:/ / www.xinhuanet.com/english/2018-10/23/ c_137553194.htm

13 Data source: Hong Kong Tourism Board, Wind.

\section{REFERENCES}

Balassa, Bela 2013. The Theory of Economic Integration. New York: Routledge. https:/ / doi. org/10.4324/9780203805183

Bertaud, Alain 2016. 'China's City Clusters: The Emergence of the Largest Urban Labor Markets in the World or Just More Congestion and Pollution?'. NYU Stern Urbanization Project.

Bie, Jiangbo, Martin de Jong, and Ben Derudder 2015. 'Greater Pearl River Delta: Historical Evolution Towards a Global City-Region'. Journal of Urban Technology 22 (2): 103-123. https://doi.org/10.1080/10630732.2014.971575

Breslin, Shaun, and Glenn D. Hook 2002. 'Microregionalism and World Order: Concepts, Approaches and Implications'. In Microregionalism and World Order. London: Palgrave Macmillan, 1-22. https://doi.org/10.1057/9781403940155_1

Chan, Sarah 2018. 'The Belt and Road Initiative: Implications for China and East Asian Economies'. The Copenhagen Journal of Asian Studies 35 (2): 52-78. https:/ / doi. org/10.22439/cjas.v35i2.5446

Cheng, Joseph Yu-shek 2014. 'The Emergence of Radical Politics in Hong Kong: Causes and Impact'. China Review 14 (1): 199-232.

Cheung, Peter T.Y. 2012. 'The Politics of Regional Cooperation in the Greater Pearl River Delta.' Asia Pacific Viewpoint.

Clover, Charles, Sherry Fei Ju, and Lucy Hornby 2017. 'China's Xi Hails Belt and Road as "project of the century"'. Financial Times, 14 May.

Enright., Michael J, Edith Elizabeth Scott, and Ka-mun Chang 2005. Regional Powerhouse: The Greater Pearl River Delta and The Rise of China. New York: Wiley.

HKAES 2017. 'Report on in the Guangdong-Hong Kong-Macao Greater Bay Area Report on Policy Study on the Integrative Development of Innovation and Technology in the Guangdong-Hong Kong-Macao Greater Bay Area'. The Hong Kong Academy of Engineering Sciences, Chinese Academy of Engineering Institute for Public Policy, The Hong Kong University of Science and Technology.

Ip, Iam-Chong 2015. 'Politics of Belonging: A Study of the Campaign Against Mainland Visitors in Hong Kong'. Inter-Asia Cultural Studies 16 (3): 410-421. https:/ / doi. org/10.1080/14649373.2015.1069054

Jha, Shikha, Sangeetha Raghuram, and Siddhant Awasthi 2019. 'Exploring Strategies for Planned Urban Cluster Development in South Asia'. ADB South Asia Working Paper Series. No. 64. https:// doi.org/10.22617/WPS190072-2

Jiang, Ziwen 2019. 'Yuegangao dawanqu jianshe lingdao xiaozu zhineng pilu (The GBA Leading Committee Function Disclosed)'. The Paper.

Johnston, Lauren A. 2019. 'The Belt and Road Initiative: What is in it for China?'. Asia $\mathcal{E}$ the Pacific Policy Studies 6 (1): 40-58. https:/ / doi.org/10.1002/app5.265

Kenderdine, Tristan 2017. 'China's Industrial Policy, Strategic Emerging Industries and Space Law'. Asia \& the Pacific Policy Studies 4 (2): 325-342. https:/ / doi.org/10.1002/ app5.177 
Kerry Liu

Kwong, Ying-Ho 2016. 'The Growth of "Localism" in Hong Kong: A New Path for the Democracy Movement?'. China Perspectives 3: 63-68.

Lau, Lawrence J. 2018. 'The Development of the Guangdong-Hong Kong-Macau Greater Bay Area'. The Greater Bay Area Forum, Shenzhen Finance Institute, Shenzhen, 19 May.

Liu, Kerry 2016. 'Chinese Renminbi after 11 August 2015'. JASSA: The Finsia Journal of Applied Finance 4: 11-20.

Liu, Kerry 2018. 'Chinese Manufacturing in the Shadow of the China-US Trade War'. Economic Affairs 38 (3): 307-324. https:/ / doi.org/10.1111/ecaf.12308

Luo, Weiteng 2018. 'HK Takes Top Slot in Global IPO Rankings'. China Daily, 20 December.

Ma, Ngok 2015. 'The Rise of "Anti-China" Sentiments in Hong Kong and the 2012 Legislative Council Elections'. The China Review 15(1): 39-66.

Porter, Michael 1998. Competitive Advantage: Creating and Sustaining Superior performance. New York: Free Press.

Rivera-Batiz, Luis A., and Paul M. Romer 1991. 'Economic Integration and Endogenous Growth'. The Quarterly Journal of Economics 106 (2): 531-555. https:// doi. org/10.2307/2937946

Qu, Hongbin and Kelvin Ho-Por Lam 2018. 'China's Greater Bay Area: Many Cities, One Goal'. HSBC Economics.

Scott, Allen J. (ed.) 2001. Global City-Regions: Trends, Theory, Policy. New York: Oxford University Press.

Te Velde, Dirk Willem. 2011. 'Regional Integration, Growth and Convergence'. Journal of Economic Integration 26(1): 1-28.

UK Parliament 2019

Venables, Anthony J. 2003. 'Winners and Losers from Regional Integration Agreements'. The Economic Journal 113 (490): 747-761. https://doi.org/10.1111/14680297.t01-1-00155

Wolman, Harold, and Diana Hincapie 2015. 'Clusters and Cluster-Based Development Policy'. Economic Development Quarterly 29 (2): 135-149. https://doi.org/10.1177/ 0891242413517136

Wong, Benjamin 2018. 'Hong Kong - Greater Bay Area: China - Belt and Road \& Beyond - The Maritime Context'. March. Invest HK.

Wu, Willa 2019. 'Bay Area Plan Aims for World Leading Center'. China Daily, 19 February.

Yang, Chun 2006. 'The Geopolitics of Cross-Boundary Governance in the Greater Pearl River Delta, China: A Case Study of the Proposed Hong Kong-Zhuhai-Macao Bridge'. Political Geography 25 (7): 817-835. https:/ / doi.org/10.1016/j.polgeo.2006.08.006

Yang, Chun 2016. 'A Cross-Boundary Mega City-Region in China under 'Two Systems': Multi-Level Governance in the Greater Pearl River Delta'. In The Ashgate Research Companion to Border Studies, ed. Doris Wastl-Walter. Farnham: Routledge, 461-478.

Yang, Chun, and Si-ming Li 2013. 'Transformation of Cross-Boundary Governance in the Greater Pearl River Delta, China: Contested Geopolitics and Emerging Conflicts'. Habitat International 40: 25-34. https:// doi.org/10.1016/j.habitatint.2013.02.001 